\title{
Defining Landscape: Resolving Contradictions at Postcolonial Omhedi, the Oukwanyama Royal Palace, Namibia
}

\author{
Napandulwe Shiweda \\ Multidisciplinary Research Centre, UNAM
}

\begin{abstract}
The history of Omhedi in north-central Namibia is not simply about place but is a site that internalizes conflictual and contradictory social forces which are inscribed in place. While Omhedi was a contested site of conflict during the war of liberation and served as a stage for ethnographic tours and photography, it has in post-colonial period come to represent a segment of important local power as it is currently the seat of the new Oukwanyama kingship. The central aim of this paper is to explain the transformation of Omhedi as a site of "spectacles" of culture during the colonial period and as the seat of Oukwanyama monarchy in post-colonial Namibia. It centrally asks how the colonial politics of the time influenced the way Omhedi was organized and accessed and the ways in which people attach meaning to and organize a sense of space and place in the postcolonial era. This paper is significant as it explores how political legitimacy can be reactivated at such a contradictory site of "traditional" power like Omhedi and what meanings these hold in terms of access in postcolonial Namibia. I conclude by raising issues of the past with the restoration of the Oukwanyama monarchy and its installation at Omhedi after independence, posing key questions about shifts in political legitimacy in both the colony and the post-colony. My analysis utilizes theories on the important use of landscape as a physical "space" for living, but also as a "place" with its meanings and contributions to societal identity. Consequently the place identity is a particular element contributing to sense of place. I argue that there exists a sense of nostalgia that many Ovakwanyama people have for a precolonial past, and the Omhedi landscape serves that purpose. In analyzing these sentiments against the construction of Omhedi as a space and place, this highlights a sense of identity and belonging that many Ovakwanyama people have towards Omhedi in default of any site with deeper legitimation or authenticity.
\end{abstract}

Keywords: Omhedi, history, post-colonial Omhedi, the colonial period, contradictions

\section{Introduction}

This paper looks at the question of Omhedi in north-central Namibia, in the period immediately after colonial occupation in 1915 to the present. It is concerned with the contest over political and social legitimacy in a former precolonial kingdom, Oukwanyama, in northern Namibia. This paper is extracted from my doctoral dissertation, "Omhedi: Displacement and Legitimacy in Oukwanyama politics, Namibia, 1915-2010" and draws on many months of field research among the Ovakwanyama people in north-central Namibia. I considered the longitudinal history of Omhedi over the period of a hundred years from World War I by highlighting the rise of the new category of colonial intermediaries, as Omhedi was central to the new regime of headmen under South African indirect rule. Through performance, display and photography, Omhedi

\footnotetext{
Napandulwe Shiweda, Ph.D., Multidisciplinary Research Centre, UNAM.
} 
became a colonial showpiece.

I present contradictory historical forces in producing Omhedi and share my findings on how political legitimacy can be reactivated at such an interesting site of "traditional" power like Omhedi and what meanings these hold in terms of access in postcolonial Namibia. This is because while Omhedi was a contested site of conflict during Namibia's war of liberation and served as a stage for ethnographic tours and photography, it has in post-colonial period come to represent a segment of important local power as it is currently the seat of the new Oukwanyama royal palace. I explain the transformation of Omhedi as a site of "spectacles" of culture during the colonial period and as the seat of Oukwanyama monarchy in post-colonial Namibia. I will ask how the colonial politics of the time influenced the way Omhedi was organized and accessed and the ways in which people attach meaning to and organize a sense of space and place in the postcolonial era.

On the onset, this research has sought to make more concrete discussions in the narrative of history by focusing around successive Ovakwanyama headmen, who played a significant role in shaping colonial rule at Omhedi. Such a layer of intermediate power has been substantially overlooked by many scholars when exploring indirect rule and its incorporation of decentralized and centralized Ovambo powers into the colonial state. Thus, the analysis of Omhedi as a place permits these important Kwanyama figures to become more salient in the history of Ovambo more broadly. As such, it informs important and ongoing scholarly work on the history of Ovambo and particularly Omhedi over the period of a century, in order to get a sense of the genesis of this intermediate stratum.

The research begins with the colonial occupation of the kingdom by Portugal and South Africa during World War I, which resulted in the displacement of the kingship to the southern half of the territory which was now bifurcated by an international boundary between Angola and then South West Africa now Namibia. Following resistance by the last king Kwanyama King, Mandume ya Ndemufayo, the institution of kingship was abolished and a Council of Headmen installed in its place. Omhedi emerged as a site of important opposition to king Mandume by a leading headman, Ndjukuma ya Shilengifa, as he became one of the senior headmen elevated to new levels of authority by colonial rule, and consolidation of the policy of Indirect Rule under South Africa, whose aim was the selective preservation of traditional customs in Oukwanyama in order to maintain stability in a time of rapid change. The main contribution of the research however is to follow this story into the second half of the 20th century, when Ndjukuma was succeeded by Nehemia Shoovaleka and then Gabriel Kautwima, at a time when nationalist opposition to South African rule was growing and old political legitimacies were tested. After independence in 1990 and the demise of Kautwima, Omhedi remained empty until the restoration of the Oukwanyama kingship occurred under postcolonial legislation on Traditional Authorities. The question becomes one of how political legitimacy can be reactivated at such a contradictory site of "traditional" power like Omhedi, now the seat of the new Kwanyama Queen. This paper engages with notions of history, landscape, and memory, as well as theories of space developed by Lefebvre and de Certeau, ${ }^{1}$ in order to understand the local reconceptualization of Omhedi as different things over different times.

A key question of this research was to look at the changes in what is now called traditional authority, from kingship prior to colonial occupation, to the headmen's council under South African administration, to current attempts to legitimize the current restored Kingship in postcolonial Namibia. This latter set of issues emerges

\footnotetext{
${ }^{1}$ See for example Noyes J. K., Colonial Space. Spatiality in the Discourse of German Southwest-Africa $1884-1915$ (Chur: Harwood Academic Publishers 1992) whose book looks at the Colonial space in German South West Africa, now Namibia. He is probably one of the researchers who previously thought about space and spatiality in the Namibian context.
} 
because after independence in 1990 and the demise of the headman Kautwima, Omhedi remained empty until the restoration of the Kwanyama kingship occurred. Thus, there was a reconfiguration of Omhedi as a place since the palace of the restored Kwanyama kingship is located there. The question becomes one of how Omhedi can be reactivated as an important place as it highlights how meanings are projected on to landscapes. Despite this, its meaning is paradoxical because it had already emerged as a site of important opposition to the anti-colonial figure of king Mandume by a leading headman, Ndjukuma ya Shilengifa, and he became one of the senior headman elevated to new levels of authority by colonial rule. But again, Omhedi is considered important today because it belonged to Ndjukuma who made space for King Mandume when he was forced to leave Ondjiva in Angola. Oral testimonies maintain that there are a number of features at Omhedi that people identify with Mandume's memory and the Oukwanyama precolonial kingship. Central to this paper is the unusual feature that Omhedi can be described ultimately as the site where people tried to stop change from taking place - not only the colonial officials and their local intermediaries, but also the current Oukwanyama Traditional Authority and the new government that has allowed the restoration of the kingship to be situated at this site.

Patricia Hayes in her $\mathrm{PhD}$ thesis states that the sharpest political change brought by colonialism was the "levelling" process of eliminating kings who were too independent and backed by armed supporters and the up-grading of headmen as substitutes where kings were removed. Cooperative kings and senior headmen then held authority in a system of indirect control by a few colonial officials that was later held up as a model of indirect rule. ${ }^{2}$ As indicated earlier, Omhedi gained prominence firstly because Ndjukuma was relocated there by King Mandume, thus marking the displacement of the Oukwanyama kingship. Secondly, after the colonial occupation Omhedi became a space where prominent headmen lived and exercised power through the activities that took place there. Thus, meaning attached to the Omhedi landscape unfolds in images, stories, rituals and the current Oukwanyama kingship that is based there. These meanings come together in shared symbols and ultimately link people to a sense of common history and individual identity. I further examine ideas about place and space in relation to the Ovakwanyama people and Omhedi as a landscape that resounds with narratives of collective history and individual experiences. Hence, I ask here how Omhedi is perceived and experienced by the Ovakwanyama, and why is it important to them. Oral histories claim that some interrogation was carried out to see which place is best suited for the restored kingship, looking at places like Omhedi, Oihole, and Ondjiva. Ondjiva and Oihole were the two places where Mandume's palaces were situated originally.

Omhedi can also be looked at as a place/space/landscape that is conceived, perceived, and lived as it is marked by dynamisms and is mediated through images and symbols. With issues regarding landscape, Stewart and Strathern argue that memory and history are interlinked with place and space. They further consider how perceptions of and values attached to landscape encode values and fix memories to places that become sites of historical identity. ${ }^{3}$ They maintain that such perceptions shift, either gradually or dramatically, over time, so that landscape becomes a form of codification of history itself, seen from the viewpoints of personal expression and experience. ${ }^{4}$ This could apply to Omhedi's landscape as it consists of features of historical importance and people relate their personal experiences and expression from the time of residence at this place. In Stewart and

2 Hayes, P., "A History of the Owambo of Namibia, 1880-1930” (unpublished PhD thesis, University of Cambridge, 1992), pp. 240-241.

${ }^{3}$ Stewart, P. J. \& Strathern, A., Landscape, Memory and History: Anthropological Perspectives (London: Pluto Press, 2003 ), p. 1.

4 Ibid., p. 1. 
Strathern's view, landscape refers to the perceived settings that frame people's senses of place and community. However, a place is a socially meaningful and identifiable space to which a historical dimension is attributed. ${ }^{5}$ Also, through an employment of the tropes-landscape, memory and history - it becomes possible to examine more closely the significance and meanings attached to Omhedi. I use these ideas in my analysis of Omhedi as I believe landscape is one of the means of conceptualizing history, identity, and legitimacy for the Oukwanyama kingship, which shifted its centre from Ondjiva to Oihole and then later and currently to Omhedi.

\section{The History of Omhedi}

However, the history of Omhedi is not simply about place. A special feature of Omhedi is that it is bound up with particular people who constitute important personages in the colonial history of northern Namibia, and Omhedi in particular. Thus an account of Omhedi necessarily weaves together certain life histories and the sequences of history through which the story of Omhedi emerges. It has therefore not been possible to write the history of a place - a "historical portrait" of an African village such as that produced by Landeg White nearly 29 years ago - through a straightforward narrative account. ${ }^{6}$ Except for 1915-17, the earlier phases of Omhedi's history in the 20th century are less important in terms of events, but raise issues that are central to the entire history of the Ovambo region. Histories of a place are never just a simple accounting of the "facts", nor are the life histories with which they are closely intertwined. They are always multiple, contested and deploy political discourses produced in specific contexts and made to serve the needs of the present. Thus, this research looks at an entire century of the history of Omhedi from the time when the Oukwanyama kingdom was bifurcated by the Namibia-Angola border during colonial occupation, to the time when Omhedi became the seat of the recently restored Oukwanyama Royal House in 2005, after many reconstructions.

In 1915, Omhedi was occupied by Ndjukuma Shilengifa, a senior headman who normally resided at Oihole on the southern side of the border. Ndjukuma was uprooted from Oihole to make space for King Mandume. This was part of the momentous changes in the Namibia-Angola border region formerly called Ovamboland, specifically in the former kingdom of Oukwanyama which straddled the border, at the time when Portuguese forces invaded northern Oukwanyama in order to occupy the border region in World War I. With these relocations, a question arises as to Ndjukuma's sentiments towards King Mandume due to his displacement from Oihole to Omhedi. It is widely alleged that he later collaborated with the South African troops to dispose of Mandume. However, there are conflicting accounts that state that there were much deeper dynastic politics or tensions within the kingdom that existed between Mandume and Ndjukuma before the South Africans appeared. ${ }^{7}$

According to oral sources, the headman Ndjukuma was a prominent man who came to power under King Weyulu ya Hedimbi in the late 19th century. Tensions worsened due to the fragmentation of central royal political and military control under Kings Weyulu and Nande (Mandume's predecessors), where princes and omalenga headmen established themselves as local power brokers by attracting followers. ${ }^{8}$ There were serious

\footnotetext{
5 Ibid., p. 4. See also, Feld, S. and Basso, K. H. (eds.), Senses of Place (New Mexico: School of American Research Press, 1997).

6 White, L. Magomero: Portrait of an African Village (Cambridge University Press, 1987).

7 Mandume came to power when the omalenga had accumulated too much power under the two previous kings, Weyulu and Nande Hedimbi and generational tension escalated when Mandume tried to curtail their power. See Hayes, P. "When You Shake a Tree" The Precolonial and the Postcolonial in Northern Namibia in Peterson, D. \& Macola, G. (eds.), Recasting the Past (Athens OH: Ohio University Press, 2009), pp. 80-81.

${ }^{8}$ Hayes, P. "A History of the Owambo of Namibia", pp. 163-164 and Kreike, E., Recreating Eden: Agro-ecological change, food security and environment diversity in southern Angola and northern Namibia, 1890-1960 (Portsmouth, NH: Heinemann, 2004$)$, p. 50.
} 
tensions that existed between King Mandume and his headmen. King Mandume asserted his control over the clients of princes, omalenga headmen, and missions alike by effecting reforms that recentralized power in royal hands and withdrew certain privileges from big headmen. For example, control over land distribution, judicial matters, communal rites, rituals, and ceremonies gave the king controlling power over his subjects. However, individuals close to Mandume's predecessors including those omalenga headmen who had made their careers under kings Weyulu and Nande, had built up considerable power, and so Mandume succeeded to the throne in 1911 faced with internal rivals. ${ }^{9}$ There were tensions between Mandume and those omalenga who had accumulated power for themselves, as they were now afraid of losing it.

Mandume ya Ndemufayo fought the South African forces in 1917 at his residence at Oihole, and died in battle. After his death, the Oukwanyama kingship was abolished. ${ }^{10}$ In reconstructing political authority in Ovamboland the South African colonial administration sought to reduce or increase power exercised by existing rulers. ${ }^{11}$ It thereupon set up a Council of Headmen consisting of eight senior-headmen in the Oukwanyama "traditional authority area" in lieu of the kingship, and divided the area into eight districts, with a senior-headman in charge of each. ${ }^{12}$ The most prominent headmen in Oukwanyama were now Nauyoma ya Mweshipandeka, Haufiku la Kasheeta, Ndjukuma ya Shilengifa, and Hamukoto wa Kaluvi. ${ }^{13}$ These headmen assumed jurisdictions which were smaller than Mandume's had been, but larger and more legitimized than any previous omalenga. ${ }^{14}$

In this regard, a central issue emerges as to how the replacement of kingship in Oukwanyama with the Council of Headmen changed the "tribal" practices after 1917. This paper argues that overall, the stakes for colonial intermediaries (council of headmen) were higher than they had been under pre-colonial rulers. The intermediaries were supposed to exert authority over ordinary people to maintain law and order, mobilize migrant labour, collect taxes, and preserve selected rituals, for instance efundula, the female initiation ceremony. Individual headmen such as Nehemia Shoovaleka held authority over a few villages, and were supposed to take collective decisions in councils.

It is important to try and understand how colonial administration influenced the Council of Headmen and manipulated tradition to legitimize a place like Omhedi and the practices that took place there. Omhedi was chosen over other headmen's places because it served as a central point for most of the colonial administration's activities in alliance with the headmen that resided there, though it was not the only site of headmen's influence. As noted earlier, Ndjukuma resided at Omhedi from 1915 when he was relocated to make space for King Mandume at Oihole. A starting point for this research therefore is to investigate the dynamics of local power when Ndjukuma resided at Omhedi. The research also looks at how Omhedi was visualized by analysing photographic collections which are rich in documenting the 1930s in Oukwanyama. This is because during Nehemia Shoovaleka's term (Ndjukuma's successor), Omhedi stood forth as a representational space for photography, tours by South African officials, and showcasing of cultural events such as efundula female initiation.

\footnotetext{
9 Hayes, P. "A History of the Owambo of Namibia”, pp. 163-164 and Kreike, E., Recreating Eden p. 51.

${ }^{10}$ Hayes, P. "Order out of chaos: Mandume Ya Ndemufayo and Oral history” Journal of Southern Africa Studies (Vol. 19, No. 1, March 1993), p. 89.

${ }^{11}$ Hayes, P. "A History of the Owambo of Namibia", p. 240.

12 Totemeyer, G., Namibia Old and New: Traditional and Modern leaders in Ovamboland (London: C. Hurst, 1978$),$ p. 45.

13 Hayes, P. "A History of the Owambo of Namibia", p. 241.

14 Ibid., pp. 240-241.
} 
At this site, a huge mass of photographs of Ovambo customs and ethnography were produced by Native Commissioner C.H.L. "Cocky" Hahn and Alfred Martin Duggan-Cronin ${ }^{15}$ who also photographed the Ovakwanyama at Omhedi. The former is said to have transformed local ritual practices into spectacles of culture. Under the influence of pre-colonial kings, Oukwanyama people (and the Ovambo more broadly) had placed emphasis on large public ritual before contact with Europeans. However, during the colonial era, Omhedi as a space was created rather sensationally to emphasize the power, authority and wealth of the headmen. At a time when indirect rule was being articulated as official policy, the colonial state staged itself through public spectacle such as the omaludi eengobe cattle festivals, efundula female initiation, and other festivals.

Although this indicates that somehow headmen and state were linked, for the colonial government allowed local intermediaries to exercise certain functions within their communities grounded in alliances with them incorporating ethnically-defined administrative components linked to the local population, they were in fact disaggregated. Hahn's support for public gatherings such as the efundula arose from the wider development of arguments concerning indirect rule, where officials were instructed to support existing structures of African authority through which colonial rule was administered. ${ }^{16}$ Hahn frequently photographed efundula ceremonies with his panoramic and other cameras. I historicise the rise of Omhedi as a photographic place and the visualisation of indirect rule because "Cocky" Hahn, the Native Commissioner for Ovamboland from 1920-1946, set up Omhedi as the crucial site for visitors to Ovambo to photograph "the native", especially during the residence of Nehemia Shoovaleka (a polygamist), one of the most important headmen in Oukwanyama. ${ }^{17}$ Efundula female initiation was seen as a spectacle during visits of the Administrator of South West Africa and other officials to Oukwanyama. Here polygamy was repeatedly offered up to the camera, and photographers continued to visit this site even after Hahn's retirement. ${ }^{18}$ It has been argued that there was a tendency towards the spectacular that might have existed before Hahn encouraged performances in public form. This is because Ovakwanyama public cultural practices in pre-colonial Oukwanyama were connected to performance (spectacle) as well as royal power. Hahn appropriated these spectacular aspects that were generated under pre-colonial conditions, promoting and extending their representational dimension through solicited performances and photographs. ${ }^{19}$ What is more, an Ovambo homestead (a replica of Nehemia's house at Omhedi) was constructed in Windhoek for the 1936 Trade Fair Exhibition.

Of course many of the photographs are of Ovambo customs and ethnography by Cocky Hahn, who was resident in Ovambo and gained knowledge of the people he ruled to be able to control them, but the photographic density at Omhedi could also be credited to visiting photographers and writers to Omhedi such as

\footnotetext{
15 Alfred Martin Duggan-Cronin was a South African/Irish photographer (1874-1954) who is well known for his photographs that he took all over southern Africa. His work is housed in the McGregor Museum in Kimberley.

${ }^{16}$ Hartmann, W., Hayes, P., Silvester, J. "Photography history and memory" in Hartman et al. (eds.), The Colonising Camera: Photographs in the making of Namibian history (Cape Town: University of Cape Town Press, 1998), p. 3.

17 See Shiweda, N. "Towards a Visual Construction of Omhedi: C. H. L. Hahn and A. M. Duggan-Cronin's photographs" paper published in André du Pisani, Reinhart Kössler and William A. Lindeke, (eds.), The Long Aftermath of War-Reconciliation and Transition in Namibia, Freiburg, Germany Arnold-Bergstraesser-Institut, 2010, Shiweda, N. "Omhedi: Displacement and legitimacy in Kwanyama Politics 1915-2010" (Unpublished PhD Dissertation, University of the Western Cape, Department of History, 2011), and upcoming Shiweda N. "Images of Ambivalence: Photography in the making of Omhedi" in Hayes, P. and Minkley, G. (Eds.) Ambivalent Photography and Visibility in African History (Wits University Press, 2016).

${ }_{18}$ See Hayes, P. "Efundula and History: Female Initiation in Pre-Colonial and Colonial Northern Namibia", paper presented at the International Workshop in Gender \& Empire, American University of Cairo, Egypt, April 2007.

19 See, Hayes, P. "Efundula and History".
} 
Alfred Martin Duggan-Cronin, Anneliese Scherz, Ernst and Ruth Damman, Negley Farson, Lawrence Green and Alice Mertens among others. ${ }^{20}$ An important motivation to highlight the photographic construction of Omhedi in this paper arises from the way the images from Omhedi came to stand for the whole of colonial Ovamboland, and had generic effects. Because of the unique accessibility of Omhedi to photographers, its history as a place is entangled with the question of projecting an overall picture of indirect rule. It is doubtless too that Omhedi was a good template for a perceived cultural homogenisation as it had qualities that were desirable or distinguishing it as an Owambo homestead.

As indicated earlier, Omhedi also catered for omaludi eengobe cattle festival which was an annual event when cattle were brought back from the main areas of residence after grazing at outposts through the long dry season. Here, cattle owners would show off their fattest cattle and thus take part in the spectacle of wealth and power. This was a displacement (or redirection) of the festival from its previous royal location. In this way, Omhedi was generalized as symbolizing a generic Ovambo “culture" through its headmen and Hahn's representations. This visualisation of Omhedi for the purposes of indirect rule is explored here in order to deconstruct the colonial image made so powerfully by Hahn at Omhedi. In the late 1960s and after Nehemia's death in 1966, Gabriel Kautwima took over as headman at Omhedi and his term lasted through the 1970s and 1980s. In the 1970s Kautwima used to have "Tribal Hearings" where public floggings and other activities were carried out at his homestead at Omhedi and at the Oukwanyama offices at Ohangwena. Of particular importance here is the General Contract Workers Strike of 1971-2, and the floggings that followed it at a time of heightened political mobilisation. Here, the colonial administration together with the Council of Headmen exercised a ritualized public violence - public floggings whose primary purpose was the ostentatious display of power. ${ }^{21}$ Sandbags and trenches were dug around homesteads of headmen Vilho Weyulu at Ohaingu, Gabriel Katamba at Onamhinda and Gabriel Kautwima at Omhedi. Sandbags formed part of a larger military infrastructure as they surrounded military bases, air bases and were filled by South African conscripts. ${ }^{22}$ These were filled with sand and often used to provide the headmen with protection at both the front and rear of the trenches that were dug around their homesteads, and were generally stacked some two or three feet deep. Thus they were used to build and reinforce protective walls around collaborative headmen. Omhedi became a target for SWAPO attacks, and many stories abound about the terror of those people who lived in its proximity.

Furthermore, Omhedi featured greatly in the 1980s when the liberation struggle waged by guerrillas of the South West Africa People's Organisation (SWAPO) intensified, because the war in the north heightened Omhedi's central importance as a location where hearings, beatings and so forth took place. Since headmen especially Kautwima played a role in the political repression, a study of Omhedi necessarily reflects on certain aspects of the liberation struggle in northern Namibia, particularly in Oukwanyama. This research also looks more generally at the opposition to colonial rule before and after the launch of the armed struggle in 1966 by young Namibian men and women, most of whom were Ovambo. Thus, this research gathered life histories

\footnotetext{
${ }^{20}$ See Miescher, G. and Rizzo, L. "Popular Pictorial Constructions of Kaoko in the 20th Century" in New Notes on Kaoko: The Northern Kunene Region (Namibia) in Texts and Photographs, edited by Giorgio Miescher and Dag Henrichsen (Basler Afrika Bibliographien 2000), p. 251 and Hartmann, W., Hayes, P., Silvester, J. "Photography history and memory" in Hartman et al. (eds.), The Colonising Camera: Photographs in the making of Namibian history (Cape Town: University of Cape Town Press, 1998), p. 187.

${ }^{21}$ See Shiweda, N. "Omhedi: Displacement and legitimacy in Kwanyama Politics 1915-2010" (Unpublished PhD Dissertation, University of the Western Cape, Department of History, 2011), and Crawford, D. J. "Wielding the Epokolo: Corporal punishment and Traditional authority in colonial Ovamboland" in the Journal of African History 56.2 (July 2015): 301-320.

${ }^{22}$ Liebenberg, J. and Hayes, P. Bush of Ghosts: Life and War in Namibia 1986-90 (Cape Town: Umuzi, 2010), p. 9.
} 
regarding this period and specific practices that used to happen at Omhedi when Kautwima resided there. The aim here is to portray how the history of a place gives a specific angle to different phases of history, from pre-colonial to postcolonial. A place such as Omhedi is given certain meanings that range across the cultural, historical, and social. This research analyses how these meanings are manipulated in the socio-political production of a place, and how these are related to what happened there within a larger colonial and later nationalist frame. Furthermore, this research asks key questions about political legitimacy at Omhedi, a site of frozen tradition but riddled with contradictions.

In the late 1990s the Ovakwanyama traditional leaders made plans for the restoration of the Kwanyama kingship and installed King Cornelius Mwetupunga Shelungu. However, in 2005, after Shelungu's death, the Ovakwanyama traditional leaders installed Queen Martha Mwadinomho ya Christian ya Nelumbu as the ohamba Queen of Oukwanyama. The queen came to reside at Omhedi where the Oukwanyama palace is now situated, whereas previously the royal capital was located at Ondjiva in southern Angola. All these shifts are connected to the history of Omhedi. The restoration took place after many years when the Ovakwanyama people had been without a king, approximately 79 years. An important question arises as to why the queen is placed at Omhedi and what significance does this place have in regard to the Kwanyama kingship. Since Kautwima's death in the mid-1990s, Omhedi was not occupied, and the residence was abandoned. Thus, why did people feel that the current Oukwanyama palace should be situated there? Was this a redefinition of Omhedi as a place in terms of it being a symbolic site for the previously displaced Kwanyama kingdom? I argue here that a place that was considered illegitimate is now made legitimate as the current Kwanyama Queen resides there.

The restoration of pre-existing pre-colonial kingships in Namibia is a recent event in the retraditionalization of regional politics and power and constitutes a very postcolonial question. There is a need for a deep ethnography of dynastic histories and politics in the face of the centralized Namibian state committed to nation-building. The shifts in power from King Mandume to Council of Headmen as a consequence of the levelling process by colonial South Africa and then the postcolonial transition to the current queen forms an intriguing case of destruction and reconstruction of royal legitimacy under different conditions. The decision to study the years between 1915 and the present is because it takes us from the beginning of South African rule in Ovamboland until independence, and they have obviously been significant in forming cultural, social, and political struggles that have led to the restoration of the kingship in the 1990s. Relatively inadequate attention has been paid to the specific nature of the cultural policy set up between the 1960s and the 1980s in Ovamboland, particularly Oukwanyama under South African rule. ${ }^{23}$ The collapse of apartheid and the attainment of independence for the Namibian people in 1990 has triggered a seeming resuscitation of old identities and renewed emphasis on the reinstallation of past kingships. But this merits deeper scrutiny.

\section{Omhedi's Redefined Landscape}

It is interesting to understand the role of the restored Oukwanyama kingship in contemporary Namibian politics, and more specifically how the Kwanyama question has influenced political debates in Namibia since its restoration in 1996. For decades after this kingship had been abolished upon the South African colonial occupation in Ovamboland, it was literally inconceivable to restore it during that period. However, the collapse

\footnotetext{
23 See Shiweda, N. "Omhedi: Displacement and legitimacy in Kwanyama Politics 1915-2010" (Unpublished PhD Dissertation, University of the Western Cape, Department of History, 2011) pp. 105-135.
} 
of apartheid and the attainment of independence for the Namibian people in 1990 has triggered a seeming resuscitation of old identities and renewed emphasis on the reinstallation of past kingships. As indicated earlier, Oukwanyama was fragmented at the time of colonial cartography and occupation by the Namibia/Angola border. Thus, the current kingship is restricted to a small place-Omhedi-as the Namibian Ovakwanyama cannot reconstitute Oihole or Ondjiva where previous kingships had located their "capital". This paper therefore deals with the question of the border and the fragmentation of the Kwanyama country from yet another angle: the postcolonial.

The question of symbolism and significance also features centrally in this paper as it analyses why Omhedi was chosen as a seat of the new kingship. Thus, this research studies why people felt that the newly restored Oukwanyama palace should be situated at Omhedi. Since Gabriel Kautwima's death in February 1995, Omhedi was not occupied, and the residence became eputu, it was abandoned. This paper asks if this was a redefinition of Omhedi as a place in terms of it being a symbolic site for the previously displaced Kwanyama kingdom. This is because previously the royal palace was located at Ondjiva and later Oihole in southern Angola. Hence, debates associated with the re-enactment of past kingdoms and motivations are explored here, bringing the substance of Omhedi as a place into deeper historical context. In this way, I present a case of the restoration of Ovakwanyama kingship at Omhedi to analyse the meaning and significance as to why it was revived after so many years.

Oral histories claim that some inquiries were conducted to see which place would be best suited for the restored kingship, looking at places like Omhedi, Oihole, and Ondjiva. Ondjiva and Oihole were the two places where Mandume's palaces were situated originally. Engela which is close to Omhedi was not considered suitable as it has okaheke, a little bush area where Bushmen's afterbirth "omashe" ovakwanghala have been buried. ${ }^{24}$ Ohaingu was also not considered as it is neighbouring a village called Oshatotwa where a marula tree resembling a pregnant woman with breasts is found, which also represents a "taboo" for the Ovakwanyama royal family. There were also talks of taking the restored kingship to Oihole, but Omhedi was chosen as a suitable place. Oral histories further claim that Omhedi and Ohaingu were the big homesteads in Oukwanyama, where king Mandume used to visit at that time. But Omhedi is more important because it belonged to Ndjukuma ya Shilengifa who made space for King Mandume. ${ }^{25}$ This is the claim of legitimacy.

As indicated earlier, Ndjukuma ya Shilengifa resided at Oihole but because of king Mandume's conflict with the Portuguese, it forced him out of his palace at Ondjiva. It was decided that Ndjukuma should leave Oihole and move to Omhedi, to make way for the King. Oral testimonies relate that Hamunyelagona who lived at Omhedi at the time had to move to Engela so that Ndjukuma could take his place at Omhedi. At the same time, Weyulu la Nakambuda who lived at Engela also moved to Oipapakane and Ndeunyema who was at Oipapakane had to move to Onekwaya. ${ }^{26}$ This whole process raises questions of place and displacement, in thinking about connections to place and movements from it, interactions across place and complex negotiations in place. It also means that questions associated with processes of negotiation between Royalty or prominent men and commoners who did not really have a choice about displacement, need to be explored fully here. Oral

\footnotetext{
24 Interview with Julia ya Mbida, Odibo, 20.08.2008.

25 Interviews with Haimbodi Haiduwa, Eembo, 2008, Sipora ya Weyulu, Ohaingu, 2008, Lucas Shinedima, Onuno, 2.08 .2008 and 23.6.2009, Elia la Haikali, Eengwena, 16.8.2008, Julia ya Mbida, Odibo, 20.08.2008, Ndationawa Nehemia, Odibo, 25.06.2009.

${ }^{26}$ Interviews with Ndahafa ya Kakonda, Omalyata, Onuno, 07.02.2009, and Vilho ya Tschilongo, Ongwediva, 18.06.2010.
} 
histories claim that people who made space or were displaced in this way did not have a problem. They claim that the relocations were all discussed with people concerned and they did not have a problem at all. It was apparently considered an honour to give up your land for the king as you became a noble and was rewarded generously. Thus, in this way, people gave each other space, deciding on who should go where and so on. ${ }^{27}$ Oral histories' general impression is that Omhedi is looked upon as very important in the history of Oukwanyama because King Mandume was initially supposed to move there. ${ }^{28}$ Thus meanings are mobile but at times do get fixed to place.

It is key therefore to ask what ways do people attach meaning to and organize a sense of space and place, in particular somewhere like Omhedi? Linking Mandume and the displacement from Ondjiva to Omhedi, one notes that the current royal Oukwanyama palace has become a way for interpreting Ovakwanyama people's experience in enacting their precolonial kingship. This points to the loss of their palace at Ondjiva in Angola, and problematizes a sense of place in many ways, relating to their bifurcated older space, the loss of capitals at Ondjiva and Oihole and the graves of their former kings. I argue that Omhedi is considered to have a sense of place for the Kwanyama population and as it provides a link to the abolished kingship. But it also means that they have reconciled with the history of problematic big headmen who lived at Omhedi. Yi-Fu Tuan has pointed out that a sense of place is often used in relation to those characteristics that make a place special or unique, as well as to those that foster a sense of authentic human attachment and belonging. ${ }^{29}$ Such characteristics are corroborated by oral testimonies that maintain that there are still a number of items at Omhedi that people identify with Mandume's memory and the Kwanyama precolonial kingship. One of these items is omwoongo wa Mandume (Mandume's marula tree) at Omhedi, named after the king because he used to tie his horse to this tree when he visited Omhedi.

When I asked why Omhedi is significant enough to become the seat of Oukwanyama restored kingship, many people responded that Omhedi represents omundilo woshilongo shaUkwanyama - the sacred ("tribal") fire for the Ovakwanyama - as the person who made space for King Mandume lived there, it was his seat. Other respondents also claim that Omhedi as a place was chosen as the seat of Oukwanyama kingship because eumbo lohamba kwali - it was a royal homestead, as it belonged to members of King Mandume's family, coming from the same clans-ovakwanangobe and ovakwanaidi. Moreover, Mandume used to visit Ndjukuma at Omhedi, so the place still has his presence. It is through such appropriations that Omhedi represents the connections with Oukwanyama Royalty and thus Queen Ohamba Martha Nelumbu now resides there. Marcel Hunziker et al. argue that an important use of landscape is a physical "space" for living, but also as a "place" with its meanings and contributions to societal identity. They emphasise that place identity is a particular element contributing to sense of place. Furthermore, landscape plays a role in psychological restoration, a notion which bridges the approaches that treat landscape as space and those which treat it as place. ${ }^{30}$ This refers to a sense of nostalgia that many Ovakwanyama people have for a precolonial past, and the Omhedi landscape serves that purpose. In analysing these sentiments against the construction of Omhedi as a space and

\footnotetext{
${ }^{27}$ Interviews with Ndahafa ya Kakonda, Omalyata, Onuno, 07.02.2009, Lucas Shinedima, Onuno, 02.08.2008 and Vatilifa Hangula, Okelemba, 04.2.2009.

${ }_{28}$ Interviews with Ndahafa ya Kakonda, Omalyata, Onuno, 07.2.2009, Lucas Shinedima, Onuno, 02.08.2008 and Vatilifa Hangula, Okelemba, 04.2.2009; Vilho ya Tschilongo, Ongwediva, 18.6.2010; Hinananye Nehova, Windhoek-West 30.01.2009 .

${ }_{29}$ Tuan, Y.-F. Space and Place: The Perspective of Experience (University of Minnesota Press, 1979), pp. 3-7.

${ }^{30}$ Hunziker, M. Bachecker, M. and Hartig, T. "Space and Place-Two Aspects of the Human Landscape Relationship" in Keinast, F. et al. (eds.) A Changing World, Challenges for Landscape Research (Springer, 2007), pp. 47-62.
} 
place, this highlights a sense of identity and belonging that many Ovakwanyama people have towards Omhedi in default of any site with deeper legitimation or authenticity.

On a more abstract level, Andrew Merrifield's study of "Place and Space: A Lefebvrian Reconciliation"31 invites us into a dialectical interpretation of place, arguing that much of the confusion in the literature on place stems from its failure to engage with the ontological nature of place. This alludes to the fact that narratives about how histories of a place such as Omhedi are projected onto a landscape, fail to connect with how people in their sense of existence look at and make meaning of a place. Merrifield proposes that a reassertion of an explicit dialectical mode of argumentation can make a major contribution to the goal that has hitherto effectively eluded geographers: that of reconciling the way in which experience is lived and acted out in place, and how this relates to, and is embedded in, political and economic practices that are operative over broader spatial scales. ${ }^{32} \mathrm{He}$ further argues that Lefebvre is adamant that this overall process of space and place production is a deeply political event, as space internalizes conflictual and contradictory social forces and social conflict is thereby "inscribed in place". This conflict arises from the inextricable tension between the usage and appropriation of place for social purposes and the domination of place (and space). ${ }^{33}$

I concur with Lefebvre's argument that the process of space and place production internalises conflictual and contradictory social forces and that social conflict is thereby "inscribed in place", but I do not agree that this is a deeply political event. This is because the production of a place or space such as Omhedi was and is a political process, and not an event. A place is marked by dynamism, it is not static as a short-term event would imply. Omhedi's different social as well as political histories and meanings are inscribed on its landscape over a period of years as it takes on a new resident and thus a different meaning. There are many layers to the making of Omhedi as a place because although oral testimonies stress its importance based on the fact that it became prominent because of Ndjukuma who made space for King Mandume, the place later became a site of many activities as discussed in this paper. Even before Mandume's death, Omhedi was associated with white colonial authority as it is understood that Hahn visited Ndjukuma at Omhedi, at the time when he was set on dividing Mandume's support and destroying remaining loyalties of the headmen to the kingship. ${ }^{34}$ This marked the political tension between king and headmen as the latter were offered increased authority in Oukwanyama in exchange for loyalty to the colonial administration. ${ }^{35}$ After Mandume's death, Omhedi became a lived space as Ndjukuma built it to be one of the greatest homesteads and conducted tours in its intricate passages. And although he was already a prominent and wealthy man, he became more so under the new dispensation - as he became senior headman under South African indirect rule.

During Nehemia's and Gabriel Kautwima's residence at Omhedi, it again represented another segment, for staged ethnographic tours and photography, and later a contested site of conflict during Namibia's war of liberation. They all left their imprints on the place. Thus, as a space, Omhedi internalizes conflictual and contradictory social forces and conflict which are thereby "inscribed in place". I further argue that a place is not merely an abstract space: it is the terrain where basic social practices-consumption, enjoyment, tradition,

\footnotetext{
31 Merrifield, A. "Place and Space: A Lefebvrian Reconciliation", in Transactions of the Institute of British Geographers, New Series, Vol. 18, No. 4 (1993), pp. 516-531.

32 Ibid.

${ }^{33}$ Merrifield, A. "Place and Space: A Lefebvrian Reconciliation", in Transactions of the Institute of British Geographers, New Series, Vol. 18, No. 4 (1993), pp. 516-531.

${ }^{34}$ Hayes, P. "The Abyss of Transition" (University of Michigan: unpublished Seminar Paper, March 2003), p. 15.

35 Hayes, P. "The Abyss of Transition” (University of Michigan: unpublished Seminar Paper, March 2003), pp. 18-19.
} 
self-identification, solidarity, social support and social reproduction, etc.-are lived out. ${ }^{36}$ It is however evident that the decision to choose Omhedi was pointedly based on the history of Ndjukuma who had made space for King Mandume at Oihole and moved to Omhedi, thus the idea is to follow that line of legitimacy and the old history. It seems Ndjukuma had more legitimacy than the other two headmen. It is however important to examine how the Kwnayama Traditional Authority edited out the bad days with Kautwima especially his involvement in the public floggings that received domestic and international attention. ${ }^{37}$

Although Omhedi was regarded as illegitimate because of its "colonial" association during colonial rule and liberation struggle respectively, Omhedi was a big house of law for Oukwanyama, it was the centre for many activities, and all headmen had their seats and gathered there for meetings, especially during Ndjukuma and Nehemia's tenure. It is more representative of the history of the Oukwanyama kingship than any other place within the Namibian border, thus I believe it was chosen for all these reasons.

\section{References}

Crawford, D. J. (2015). Wielding the Epokolo: Corporal punishment and traditional authority in colonial Ovamboland. Journal of African History, 56(2), 301-320.

Feld, S., \& Basso, K. H. (eds). (1997). Senses of place. New Mexico: School of American Research Press.

Hartmann, W., Hayes, P., \& Silvester, J. (1998). Photography history and memory. In Hartman et al. (Eds.), The colonising Camera: Photographs in the making of Namibian history. Cape Town: University of Cape Town Press.

Hayes, P. (1992). A history of the Owambo of Namibia, 1880-1930 (unpublished PhD thesis, University of Cambridge).

Hayes, P. (2007). Efundula and History: Female Initiation in Pre-Colonial and Colonial Northern Namibia (paper presented at the International Workshop in Gender \& Empire, American University of Cairo, Egypt, April 2007).

Hayes, P. (2003). The abyss of transition (University of Michigan: unpublished Seminar Paper, March 2003).

Hayes, P. (1993). Order out of chaos: Mandume Ya Ndemufayo and Oral history. Journal of Southern Africa Studies, 19(1).

Hayes, P. (2009). "When You Shake a Tree". The precolonial and the postcolonial in Northern Namibia. In D. Peterson and G. Macola (Eds.), Recasting the past. Athens OH: Ohio University Press.

Hunziker, M., Bachecker, M., \& Hartig, T. (2007). Space and place-Two aspects of the human landscape relationship. In F. Keinast et al. (Eds.), A changing world, challenges for landscape research. Springer.

Kreike, E. (2004). Recreating Eden: Agro-ecological change, food security and environment diversity in southern Angola and northern Namibia, 1890-1960. Portsmouth, NH: Heinemann.

Liebenberg, J., \& Hayes, P. (2010). Bush of ghosts: Life and war in Namibia 1986-90. Cape Town: Umuzi.

Merrifield, A. (1993). Place and space: A Lefebvrian Reconciliation. In Transactions of the Institute of British Geographers, New Series, 18 (4).

Miescher, G., \& Rizzo, L. (2000). Popular Pictorial Constructions of Kaoko in the 20th Century. In G. Miescher and D. Henrichsen (Eds.), New notes on Kaoko: The Northern Kunene region (Namibia) in texts and photographs. Basler Afrika Bibliographien.

Noyes, J. K. (1992). Colonial space. spatiality in the discourse of German Southwest-Africa 1884-1915. Chur: Harwood Academic Publishers.

Shiweda, N. (2011). Omhedi: Displacement and legitimacy in Kwanyama Politics 1915-2010 (unpublished PhD Dissertation, Department of History, University of the Western Cape).

Shiweda, N. (2010). Towards a Visual Construction of Omhedi: C. H. L. Hahn and A. M. Duggan-Cronin's photographs' paper. In André du Pisani, Reinhart Kössler and William A. Lindeke (Eds.), The long aftermath of war-Reconciliation and transition in Namibia. Freiburg, Germany: Arnold-Bergstraesser-Institut.

Stewart, P. J., \& Strathern, A. (2003). Landscape, memory and history: Anthropological perspectives. London: Pluto Press. Totemeyer, G. (1978). Namibia old and new: traditional and modern leaders in Ovamboland. London: C. Hurst.

\footnotetext{
36 Merrifield, A. "Place and Space", pp. 516-531.

37 See Shiweda, N. "Omhedi: Displacement and legitimacy in Kwanyama Politics 1915-2010" (Unpublished PhD Dissertation, University of the Western Cape, Department of History, 2011), pp. 158-196 and pp. 197-232.
} 
Tuan, Y.-F. (1979). Space and place: The perspective of experience. University of Minnesota Press.

White, L. (1987). Magomero: Portrait of an African village. Cambridge University Press. 